Print- ISSN: 1391-586X, E-ISSN: 2602-9030, Copyright @ 2020 by Faculty of Science, Eastern University, Sri Lanka.

\title{
SMALL SCALE BIODIESEL PRODUCTION FROM Sargassum sp AND OPTIMIZATION OF CONDITIONS FOR YIELD ENHANCEMENT
}

\author{
Mercy Nimal Fernando and Ranganathan Kapilan* \\ Department of Botany, University of Jaffna, Sri Lanka
}

\begin{abstract}
Production of biofuel from excessive natural resources and underutilized plant materials has drawn global attention due to its cost effectiveness, eco friendliness and sustainability compared to the conventional fossil fuels. This work was aimed to select the best marine flora available in the Northern Sri Lankan sea to produce biodiesel and to optimize the conditions to enhance the yield. Sargassum sp., Ulva fasciata, Turbinaria ornata, Gelidium sp. and Thalassia sp. were collected from the coastal region of the Jaffna peninsula and washed thoroughly sun-dried. The organic solvents used to extract oil from these algal and sea grass species were n-hexane and di-ethyl ether, while alkaline catalysts were used to convert the extracted oil into biodiesel via transesterification reaction. When the oil extraction was done separately from the five dried marine plant species using n-Hexane and Di-ethyl ether as solvents, significantly higher quantity of oil was obtained from Sargassum sp. than the other tested algal and plant species, hence Sargassum $s p$. was selected for further studies. When the conditions for the extraction of oil from Sargassum sp. such as Sargassum to solvent(n-Hexane: Di-ethylether) ratio (0:200), amount of algal biomass $(100 \mathrm{~g})$, longer contact time (24h), molar ratio (4:1), catalyst amount $(0.6 \%)$, temperature (60 $\left.{ }^{\circ} \mathrm{C}\right)$, reaction time (25min) were optimized before the conversion of oil into biodiesel via transesterification reaction, there was a significant increase in the quantity of extracted oil by 11.7 times than the non-optimized conditions. Since the density of the biodiesel $\left(867.3 \mathrm{~kg} / \mathrm{m}^{3}\right)$ meets the international standards, the quality of the biodiesel produced from Sargassum sp. could be recommended as satisfactory. Large scale multicenter studies need to be done in order to confirm and implement this finding.
\end{abstract}

Keywords: Biodiesel, Sargassum sp, Trans-esterification, Oil extract, Optimization

*Corresponding author: ranganat@ualberta.ca

iD https://orcid.org/0000-0002-7608-1615 


\subsection{INTRODUCTION}

Continued usage of petroleum sourced fuels is now widely recognized as unsustainable, because of depleting supplies. Contribution of the fossil fuels to the accumulation of carbon dioxide in the environment is significantly higher thus they lead to greenhouse effect [1]. The cost of crude oil will continue to rise due to diminishing supply, therefore the production of fuels from alternate sources will be very much needed in the future decades [2]. In this scenario, biodiesel could be considered as one of the best alternative fuels due to its nontoxic nature [3]. Biodiesel has attracted attention during the past few years as a renewable and environmentally friendly fuel because of diminishing petroleum reserves and the deleterious environmental consequences of exhaust gases from petroleum diesel $[4,5]$. Biodiesel is the monoalkyl esters of long fatty acids, which is derived from trans-esterification of biological substances [6]. The recent researches have proven that oil production from algae is clearly superior to that of terrestrial plants such as palm, grape seed, soy beans and has potential to completely displace fossil fuel [7, 8, 9]. Marine and freshwater flora can contribute between $20-80 \%$ of the oil production by weight of their dry mass [10]. Marine flora shows much faster growth rates than terrestrial crop plants. The per unit area yield of oil from algae is estimated to be from 20,000 to 80,000 L per acre per year. The use of marine flora as energy crops has potential benefits, due to their easy adaptability to growth conditions, the possibility of growing in adverse environments, either in fresh or marine waters avoiding the use of land [11]. Furthermore, two thirds of earth's surface are covered with water, thus marine algae and plants would truly be renewable option of great potential for global energy needs [12]. Biodiesel offers a major economic advantage over other non- renewable energy sources [13]. It is used as biofuel, power generation [14,15] petrol additive [16, 17] to increase the octane rating and as a solvent [17]. Objectives of the study were to produce biodiesel from different marine flora and to optimize the conditions for biodiesel production from the selected marine flora before and during transesterification reactions in order to enhance the biodiesel yield.

\subsection{MATERIALS AND METHODS}

\section{Sources of algal species}

Marine macro flora such as brown algae Sargassum sp., Turbinaria ornata (Class: Phaeophyceae), green algae Ulva fasciata (Class: Ulvophyceae), red algae Gelidium sp., (Class: Florideophyceae) and marine sea grass Thalassia sp. were collected from coastal area of the Jaffna peninsula located in the Northern Sri Lanka.

\section{Pretreatment of algal species}

The samples were washed thoroughly two to three times using tap water. Then they were directly exposed to sunlight for one week to get a dried biomass. The dried samples were ground separately and the fine powder was passed through a $500 \mu$ sieve [18]. 


\section{Treatment with solvents}

\section{Treatment with hexane}

Oils were obtained by extracting the algae $(10 \mathrm{~g})$ with hexane in a soxhlet extractor for $9 \mathrm{~h}$. The extracted oil was separated by evaporating the solvent in a rotary evaporator at $45^{\circ} \mathrm{C}$ for 15 min.

\section{Treatment with di-ethylether}

$100 \mathrm{~g}$ of fine powder of each sample was weighed and added in to $500 \mathrm{ml}$ brown bottle containing $200 \mathrm{ml}$ di-ethylether. The solution was covered and shaken every 30min for $6 \mathrm{~h}$ and allowed to stand for twenty-four hours in room temperature $\left(27-30^{\circ} \mathrm{C}\right)$. Then it was shaken well and filtered through Buchner funnel suction pump using Whatman (No.1) paper. After filtration, the solvent was removed by evaporation using a rotary evaporator under reduced pressure and at a temperature below $35^{\circ} \mathrm{C}$ [19]. About $3.3 \mathrm{~g}$ crude extract was obtained and separated through the extraction process from $10 \mathrm{~g}$ sample of algal or seagrass. The extracted oil was converted into biodiesel through transesterification reaction in the presence of methanol. In this process triglycerides reacts with alcohols to form the fatty acid ester (biodiesel) and the glycerol [20]. During this reaction the alga and Thalassia oil was allowed to react with the methanol in the presence of alkaline $\mathrm{NaOH}$.

\section{OPTIMIZATION OF CONDITIONS FOR BIODIESEL PRODUCTION}

\section{Optimized condition for extraction of oil from marine floral biomass}

\section{Effect of biodiesel production from different marine floral species}

Soxhlet apparatus thimble was filled with $10 \mathrm{~g}$ of Sargassum sp., dissolved in $200 \mathrm{ml}$-hexane and allowed $9 \mathrm{~h}$ for oil extraction. The same oil extraction process was followed for all the tested algal and sea grass samples

Percentage of biodiesel yield $=\underline{\text { Biodiesel yield }} * 100[21,22]$

Oil used

\section{Effect of solvent ratio}

Experimental setup was made by adding different solvent ratio (hexane:di-ethylether 200:0, 100:100,0:200) in a10g of marine floral biomass and the percentage oil yield was determined at the end.

\section{Effect of algal biomass}

Oil extraction setup was made by optimized Sargassum sp., optimized solvent ratio (hexane:diethylether 200:0) with different amount of ground algal biomass (10 g, 20 g, 40 g, 60 g, 80 g, 100 g). Same process was repeated for all the algal species under the optimized conditions. 


\section{Effect of contact time}

Optimized Sargassum biomass $100 \mathrm{~g}$ was placed on the thimble and experimental setup was allowed for different time periods $(6 \mathrm{~h}, 9 \mathrm{~h}, 12 \mathrm{~h}, 18 \mathrm{~h}, 24 \mathrm{~h})$ with optimized solvent ratio (hexane:di-ethylether 200:0).

\section{Optimization of conditions for transesterification reaction}

\section{Effect of molar ratio of methanol to algae}

Oil extraction experimental setup was done by Sargassum sp., optimized solvent ratio (hexane: diethylether 200:0) optimized algal biomass100 g, and allowed for optimized time period (24h). Following mol ratio methanol to algal biomass was added to optimized transesterification reaction $(2: 1,3: 1,4: 1,5: 1,6: 1,7: 1)$.

\section{Effect of catalyst amount}

Oil extraction test arrangement was made with Sargassum sp, with the advanced dissolvable proportion (hexane:diethylether; 200:0), improved algal biomass $100 \mathrm{~g}$ and took into account streamlined timeframe $(24 \mathrm{~h})$. Optimized methanol to oil proportion $4: 1$ was included with the accompanying impetus sum $(\mathrm{NaOH})$ individually $0.3 \%, 0.4 \%, 0.5 \%, 0.6 \%, 0.7 \%$ and $0.8 \%$ for transesterification response [23].

\section{Effect of temperature}

Oil extraction trial arrangement was made with Sargassum, with the improved dissolvable proportion (hexane: diethylether;200:0), optimized algal biomass $100 \mathrm{~g}$ and considered upgraded timeframe $(24 \mathrm{~h})$ under enhanced transesterification response condition (molar proportion methanol to oil 4:1) with the streamlined impetus sum $0.7 \%(\mathrm{NaOH})$ were blended utilizing attractive stirrer by different response time $5 \mathrm{~min}$ to $30 \mathrm{~min}$ [24, 25] and that blend was poured in to oil. This item was kept $35{ }^{\circ} \mathrm{C}$ to $60{ }^{\circ} \mathrm{C}$ diverse temperature in a water bath.

\section{Effect of reaction time}

Oil extraction preparation was finished with Sargassum, enhanced dissolvable proportion (hexane:diethylether 200:0), upgraded algal biomass $100 \mathrm{~g}$, took into consideration advanced timeframe $24 \mathrm{~h}$, streamlined transesterification response condition molar proportion methanol to oil 4:1,optimized impetus sum $0.7 \%(\mathrm{NaOH})$ were through blended utilizing attractive stirrer , and the blend was poured in to oil. This item was $60{ }^{\circ} \mathrm{C}$ with improved temperature and taking into consideration $5 \mathrm{~min}$ to $30 \mathrm{~min}$ to response happened in water bath [26].

\section{Statistical analysis}

All the experiments were made in triplicates and the average values were used to plot the graphical representation. Statistical analyses were performed using Minitab 17.0 version. The data were 
analyzed using one- way ANOVA. Tukey's multiple comparison test was used to determine significant difference at $\mathrm{p}<0.05$.

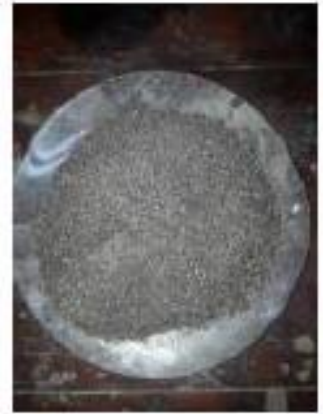

a

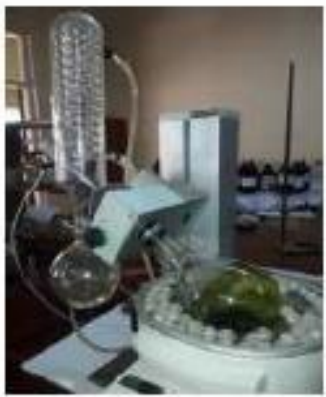

$\mathrm{d}$

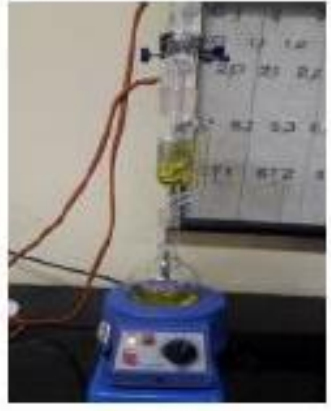

b

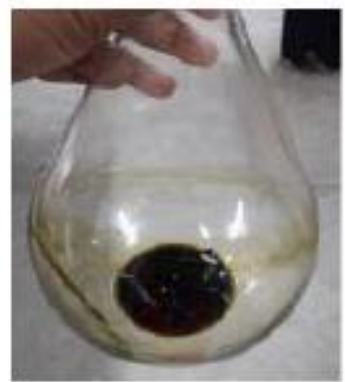

e

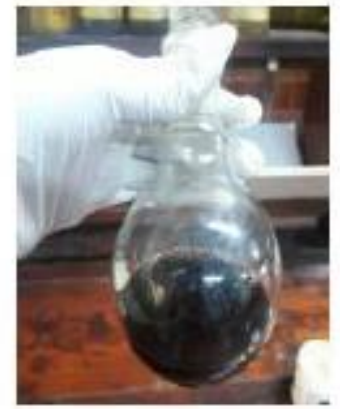

c

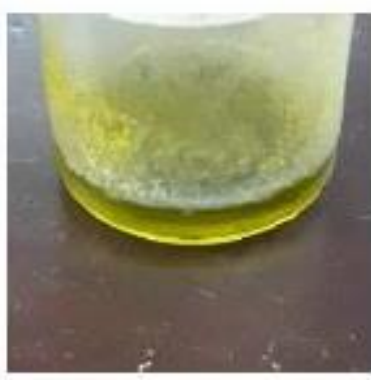

f

Figure 1: Stepwise process of exraction (a) Ground algal biomass, (b) Oil extration by soxhlet apparatus, (c) Oil and solvent mixture, (d) Solvent evaportion by rotary evaporator, (e) Extracted oil, methanol and $\mathrm{NaOH}$, (f) Unpurified biodissel.

\subsection{RESULTS AND DISCUSSION Extraction of oil from algal biomass}

\section{Effect of biodiesel production from different marine flora}

From these marine algae and seagrass species (Sargassum, Ulva, Turbinaria, Thalassia, Gelidium) higher amount of oil producing marine flora was selected by, based on following properties. Amount of oil produced by marine floral, amount of crude extract, $\mathrm{pH}$ of oil from marine floral species. The amount of oil yield from Sargassum, Ulva, Turbinaria, Thalassia, Gelidium were $11.6 \mathrm{ml}, 5.2 \mathrm{ml}, 4.8 \mathrm{ml}, 2.3 \mathrm{ml}, 0.9 \mathrm{ml}$ (Figure 2) respectively and the amount of crude extract (oil + residue) were 3.3gram, $2.7 \mathrm{~g}, 1.9 \mathrm{~g}, 1.5 \mathrm{~g}, 0.7 \mathrm{~g}$ (Figure 3) respectively. Significantly the highest amount of oil yield $(11.6 \mathrm{ml})$ and the crude extract $(3.3 \mathrm{~g})$ were obtained from Sargassum than the other species. Amount of oil produced by marine algae and seagrass species, and the amount of crude extract were directly proportional to the quantity of the oil produced and the final biodiesel yield. There was no significant difference in the $\mathrm{pH}$ values of the biodiesels produced among the different algal and plant species tested (Figure 4). Researches done in the past were also reconfirmed by this finding $[15,16]$. 


\section{Effect of solvent ratio}

When different solvent ratio hexane:di-ethylether was used in the extraction process, significantly higher amount of fraction of oil yield (0.0751) was obtained with Sargassum sp. The effect of solvent ratio on hexane:di-ethylether percentage of oil yield extracted is shown in Table 1. Hexane has great ability to extract oil when compare to di-ethyl ether with a boiling point of $69{ }^{\circ} \mathrm{C}$ it is able to retain its liquid stage at all atmospheric conditions than for extreme climates. Contrast to hexane, di-ethyl ether is high volatile solvent boiling point $\left(34^{\circ} \mathrm{C}\right)$ approximately equal to room temperature. Because of this reason, the oil extraction of hexane: di-ethylether,0:200 ratio was not possible with soxhlet apparatus method. Therefore, ratio hexane: di-ethyl ether, 0:200 was tried using Buchner funnel suction pump method. [27, 28].

\section{Effect of algal amount}

When the amount of algal biomass initially used was $100 \mathrm{~g}$, oil yield was significantly increased by $68 \%$ with Sargassum sp. than the other tested marine species. Oil yield was increased with the increasing amount of biomass (Figure 5). Therefore, in addition to the quantity of the algal sample, it could be concluded that the size of the algal particles also influenced in the final oil yield. [29, 30].

Table 1: Amount of oil extracted using different solvent combination

\begin{tabular}{cccc}
\hline S.no & n-Hexane $(\mathbf{m l})$ & di-ethyl ether $(\mathbf{m l})$ & $\begin{array}{c}\text { Fraction of oil } \\
\text { extracted }\end{array}$ \\
\hline $\mathbf{1}$ & 200 & 0 & $\mathbf{0 . 0 7 5 1 *}$ \\
\hline $\mathbf{2}$ & 0 & 200 & 0.0321 \\
\hline $\mathbf{3}$ & 100 & 100 & 0.0542 \\
\hline
\end{tabular}

\section{Effect of contact time}

When the contact time was varied from 5 to $24 \mathrm{~h}$, significantly higher oil yield was obtained $(10.18 \%)$ with Sargassum species at $24 \mathrm{~h}$. Percentage yield at larger contact time could be explained by the fact that enhanced interaction between the solvent and biomass occurred after long contact time, which lead to homogenous mixing [31]. It was found that the biodiesel with higher oxidation stability is preferable as low oxidation stability can affect the quality of biodiesel. Biodiesels with poor oxidation stability can be easily remedied by adding antioxidants during this reaction [32]. Therefore, $24 \mathrm{~h}$ (Figure 6) would be sufficient enough to facilitate the oxidation process and oil yield from the plant substrate $[8,33,34]$. 


\section{Transesterification reaction}

\section{Effect of molar ratio of methanol to oil}

The stoichiometric ratio for transesterification requires 3 moles of alcohol and 1 mole of triglyceride to yield three moles of fatty acid alkyl esters and one mole of glycerol. However, higher quantity of alcohol is preferred to shift the equilibrium to form esters [20]. In this study, different range of 6 molar ratios of methanol to algal oil $(2: 1,3: 1,4: 1,5: 1,6: 1,7: 1)$ were examined. Significantly higher amount of biodiesel was obtained at 4:1 methanol to oil ratio than the other ratios used (Figure7). When higher molar ratio of methanol to oil is increased, the excess amount of oil promotes the forward reaction [35]. When the range of methanol to oil ratio was 2:1 to $7: 1$, maximum yield was obtained $(0.945 \%)$.

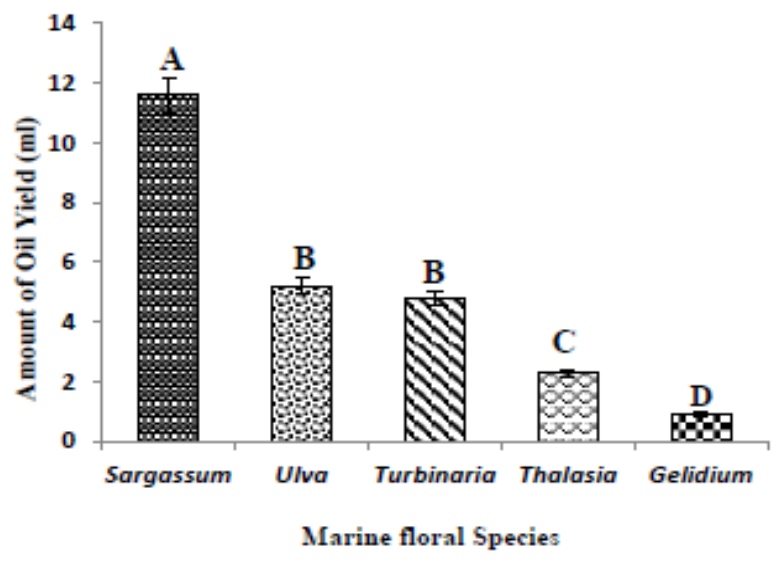

Figure2: Effect of oil yield from selected marine floral species

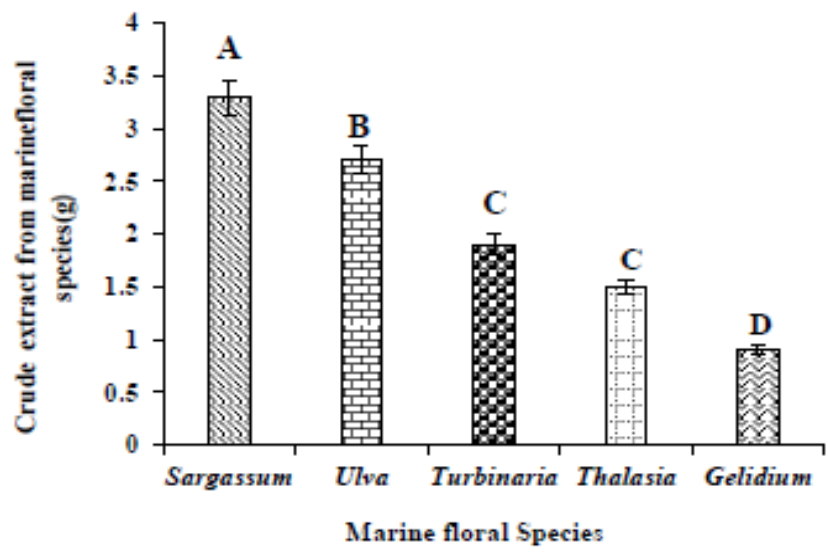

Figure 3: Effect of crude extract from selected marine floral species

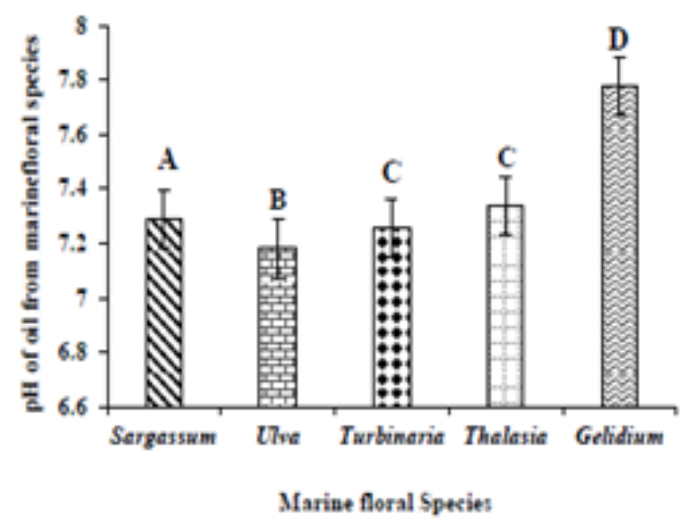

Flgure4: Effect of Ph of oll from selected marlne floral specles 

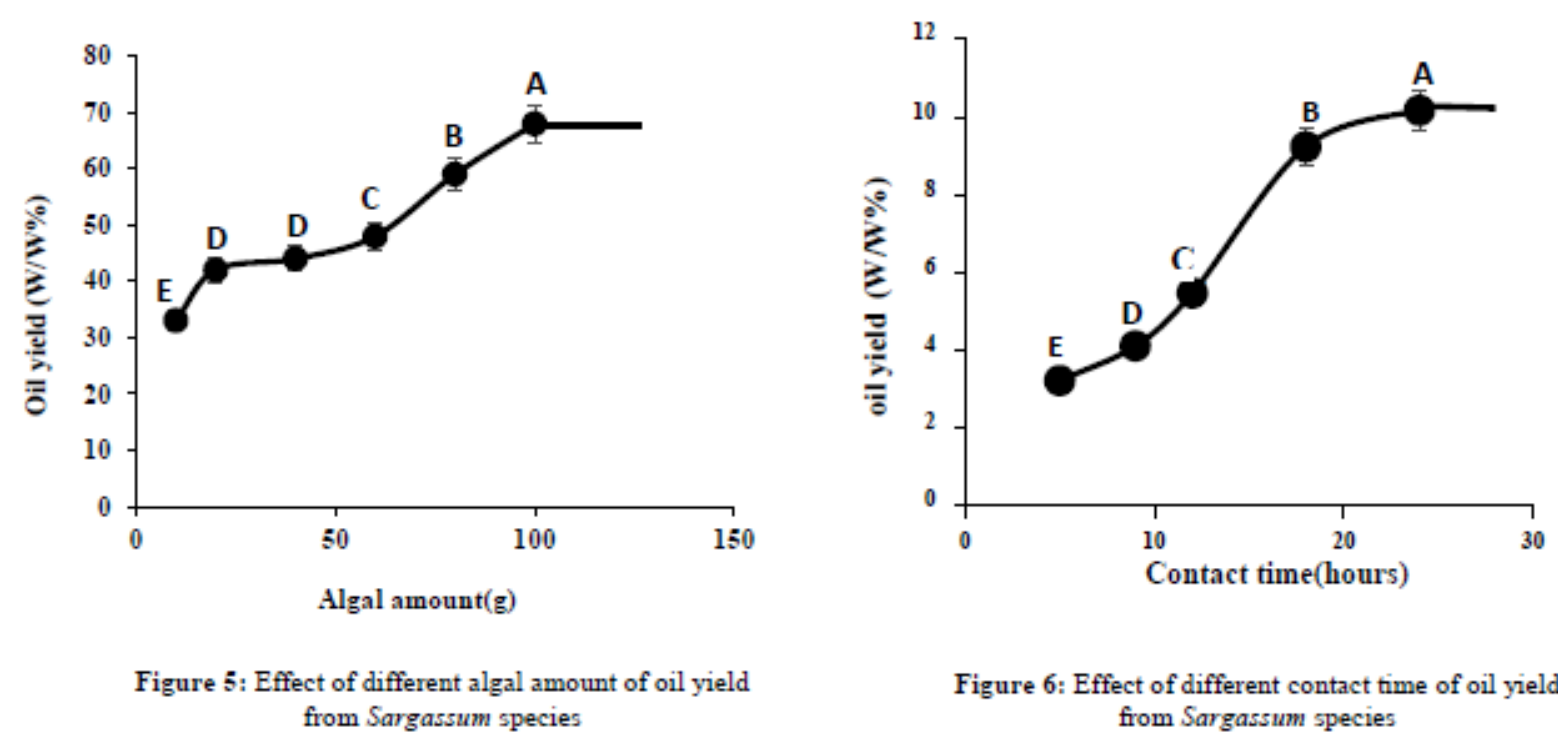

Figure 6: Effect of different contact time of oil yield from Sargassum species

\section{Effect of catalyst amount}

When different amounts of catalyst $(0.2,0.4,0.6,0.8,1.0)$ were used, significantly higher amount of biodiesel production $(0.93 \%$ - Figure 8 ) was obtained when $0.6 \%$, and $0.7 \%$ were used. The role of catalyst in transesterification reaction is very important. This reaction can be carried out with both, acid or alkali catalyst. However, using acidic catalyst has the disadvantages due to elevated rate of transesterification reaction and the reaction conditions are mild, consumption of methanol is significantly less, catalyst is less corrosive, and the acid catalyst process requires a high methanol to oil molar ratio and high acid catalyst concentration [14]. Commonly used alkaline catalysts include $\mathrm{NaOH}$ and $\mathrm{KOH}$. In this study $\mathrm{NaOH}$ was used because of its cheap and effective [31, 36, 37].

\section{Effect of temperature}

The biodiesel production was obtained after the addition of methanol and alkali catalyst mixture to oil, these were kept under different temperature range $35{ }^{\circ} \mathrm{C}$ to $70{ }^{\circ} \mathrm{C}$. Maximum amount of biodiesel was produced in between $45{ }^{\circ} \mathrm{C}$ to $60{ }^{\circ} \mathrm{C}$ temperature range. Therefore, the temperature has a considerable influence in the biodiesel yield produced. In this study, significantly higher biodiesel production was obtained at $60{ }^{\circ} \mathrm{C}$, which is in the agreement with the available literature $[38,39]$. When the temperature was optimized as $60^{\circ} \mathrm{C}$, biodiesel production was increased by 9.4 times (from $0.1 \%-0.942 \%$ ) than the non-optimized condition. At $60{ }^{\circ} \mathrm{C}$, biodiesel yield was 0.942 $\%$ and this was the maximum quantity for the production of biodiesel because there is a limitation in the boiling point of methanol. Biodiesel would reduce the amount of methanol used in the reaction mix, because of the forward reaction in transesterification reaction, so that the methanol becomes insufficient for further reactions. At $70{ }^{\circ} \mathrm{C}$, biodiesel yield was $1.81 \%$ (Figure 9) and the 
reduction might be due to the higher temperature that could accelerate the saponification of triglycerides and had a negative effect on the product yield. Moderately higher temperatures in addition to the carbon source induce saponification of triglycerides in the formation of soap [17, 26].

\section{Effect of reaction time}

When the reaction time was kept at 25 minutes, biodiesel yield significantly increased (1.1 times Figure 10) than the non-optimized reaction time. The reaction time required for the optimization of the alkaline catalyst transesterification reaction depends not only in the reaction temperature, but also on the degree of mixing in the process [40]. The reaction rate of the transesterification increased with the increasing temperature and the rate of mixing and this confirms the previous findings [41].

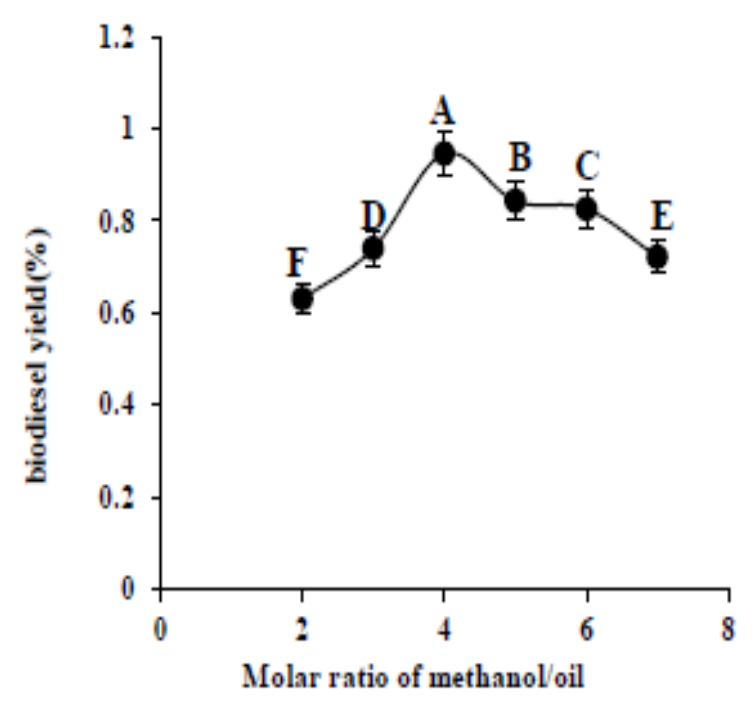

Figure7: Effect of different molar ratio of methanol/oil of biodiesel yield from Sargassum species

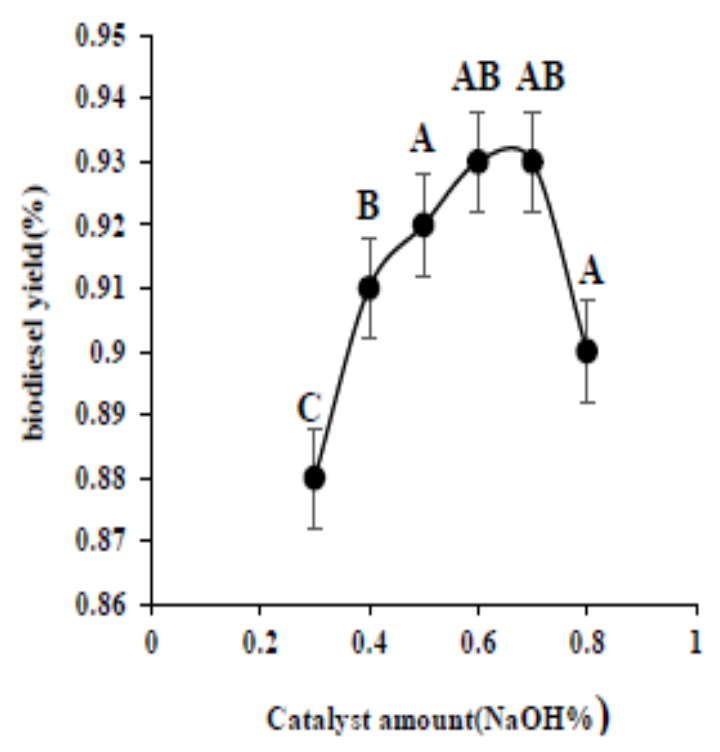

Figure 8: Effect of different catalyst amount of biodiesel yield from Sargassum species 


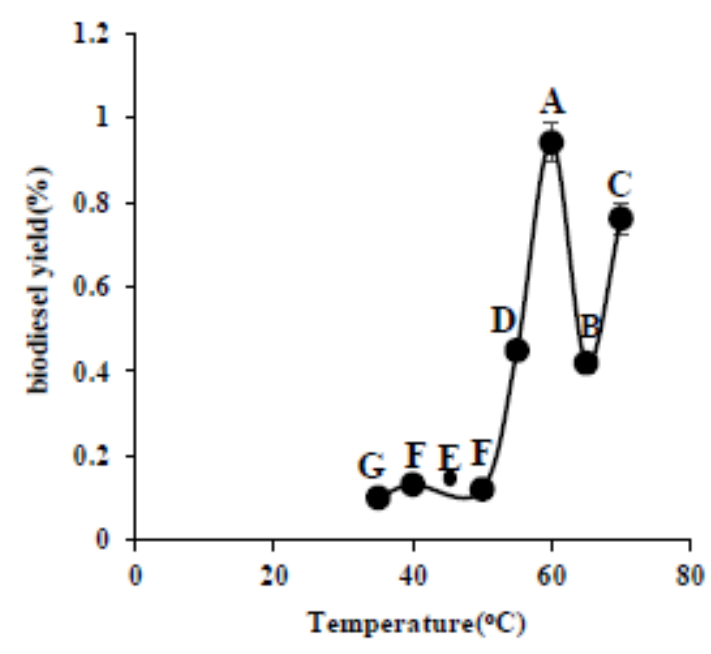

Figure 9: Effect of different temperature of biodiesel yield from Sargassum species

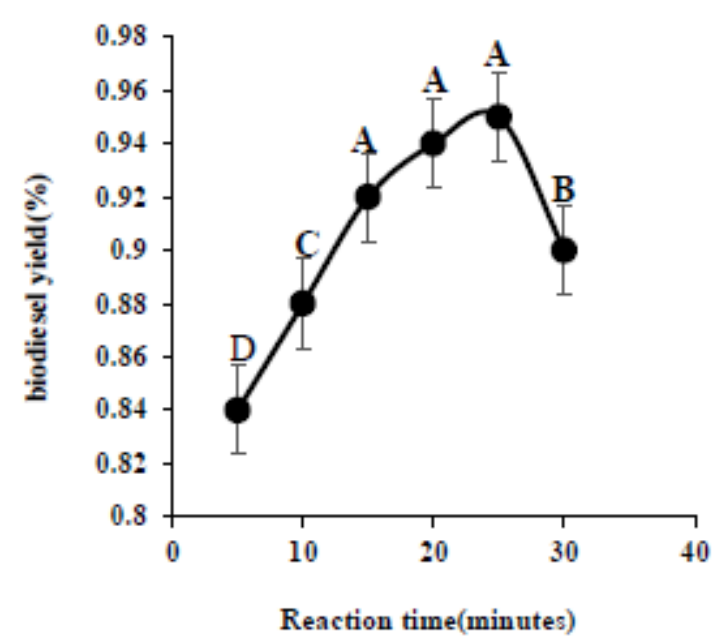

Figure10: Effect of different reaction time of biodiesel yield from Sargassum species

\section{Biodiesel analysis}

The quality of biodiesel was assessed by measuring its properties such as flash point, fire point, cloud point and density as shown in Table 2. There was no significant difference between, petrodiesel and the produced biodiesel in the major biodiesel properties. Properties of the produced biodiesel fulfilled the international standards set by the USA ASTM D6751. The physical and chemical properties of the produced biodiesel, along with results from other researchers' work on similar biodiesels, are compared with other non-edible biodiesels and petrodiesel and it was found that all the properties and qualities of the biodiesel fulfilled the international standards (USA ASTM D6751 and European Union EN14214) [42, 43]. Since the density of the biodiesel $\left(867.3 \mathrm{Kgm}^{-3}\right.$ ) falls between the internationally accepted standards, the quality of the biodiesel produced from Sargassum sp. could be recommended as satisfactory. Many researchers showed that densities of biodiesels do not vary considerably, as the density of methanol and oil are close to the density of produced biodiesel, which usually varies between 850 and $900 \mathrm{Kgm}^{-3}$ [44, 45, 46].

Table 2: Comparison of the biodiesel properties with the petrol diesel

\begin{tabular}{lcc}
\hline Properties & Petro diesel & Biodiesel \\
\hline Flash point $\left({ }^{\circ} \mathrm{C}\right)$ & 134 & 142 \\
\hline Fire point $\left({ }^{\circ} \mathrm{C}\right)$ & 154 & 159 \\
\hline Cloud point $\left({ }^{\circ} \mathrm{C}\right)$ & 4 & 3 \\
\hline Density $\left(\mathrm{Kgm}^{-3}\right)$ & 865.2 & 867.3 \\
\hline
\end{tabular}




\subsection{CONCLUSION}

Among the marine flora (algae and Thalassia sp.) tested, brown macroalgae, Sargassum sp was an efficient raw material for the biodiesel production, where oil extraction and transesterification were the two prime steps. Oil yield from Sargassum sp. was significantly increased by 3 times after optimization of pre-transesterification conditions such as solvent ratio, algal amount, and contact time. Biodiesel yield from Sargassum sp. was significantly increased by 11.7 times after transesterification conditions such as molar ratio methanol/oil, catalyst amount, reaction temperature, reaction time. Optimization of conditions before and after transesterification, significantly increased the biodiesel yield from the dry mass of Sargassum sp. Since the density of the biodiesel $\left(867.3 \mathrm{Kgm}^{-3}\right)$ meets the international standards, the quality of the biodiesel produced from Sargassum sp. could be recommended as satisfactory. Therefore, widely spread excessively available marine Sargassum sp. could be a good natural source for the production of biodiesel. Large scale multicenter studies and efficient purification procedures need to be carried out in order to proceed this towards commercial applications.

\subsection{REFERENCES}

[1] Demirbas, A., (2009). Progress and recent trends in biodiesel fuels. Energy conversion and management, 50(1):14-34.

[2] Du, W., Li, W., Sun, T., Chen, X. and Liu, D., (2008). Perspectives for biotechnological production of biodiesel and impacts. Applied Microbiology and Biotechnology, 79(3):331-337.

[3] Lapinskienè, A., Martinkus, P. and Rebzdaite, V., (2006). Eco-toxicological studies of diesel and biodiesel fuels in aerated soil. Environmental Pollution, 142(3):432-437.

[4] Van Gerpen J (2015). Biodiesel processing and production. Fuel Processing Technology, 86(10):1097-1107.

[5] Fon-Sing, S. and Borowitzka, M.A., (2016). Isolation and screening of euryhaline Tetraselmis sp. suitable for large-scale outdoor culture in hypersaline media for biofuels. Journal of Applied Phycology, 28(1):1-14.

[6] Lapuerta, M., Armas, O. and Rodriguez-Fernandez, J., (2008). Effect of biodiesel fuels on diesel engine emissions. Progress in energy and combustion science, 34(2):198-223.

[7] Chisti, Y., (2007). Biodiesel from microalgae. Biotechnology advances, 25(3):294-306.

[8] Srivastava, A. and Prasad, R., (2000). Triglycerides-based diesel fuels. Renewable and sustainable energy reviews, $\mathbf{4 ( 2 ) : 1 1 1 - 1 3 3 .}$

[9] Suganya, T., Gandhi, N.N. and Renganathan, S., (2013). Production of algal biodiesel from marine macroalgae Enteromorpha compressa by two step process: optimization and kinetic study. Bioresource technology, 128:392-400. 
[10] Bajhaiya, A.K., Mandotra, S.K., Suseela, M.R., Toppo, K. and Ranade, S., (2010). Algal biodiesel; The next generation biofuel for India. Asian J. Exp. Biol. Sci, 4:728-739.

[11] Lee, D.H., (2011). Algal biodiesel economy and competition among bio-fuels. Bioresource technology, 102(1):43-49.

[12] Patil, P.D. and Deng, S., (2009). Optimization of biodiesel production from edible and non-edible vegetable oils. Fuel, 88(7):1302-1306.

[13] Hossain, A.S., Salleh, A., Boyce, A.N., Chowdhury, P. and Naqiuddin, M., (2008). Biodiesel fuel production from algae as renewable energy. American journal of biochemistry and biotechnology, 4(3):250-254.

[14] Lipper, L. and Zilberman, D., (2018). A short history of the evolution of the climate smart agriculture approach and its Links to climate change and sustainable agriculture debates. In Climate Smart Agriculture Springer, Cham, 13-30.

[15] Mata, T.M., Martins, A.A. and Caetano, N.S., (2010). Microalgae for biodiesel production and other applications: a review. Renewable and sustainable energy reviews, 14(1): 217-232.

[16] Maceiras, R., Rodr1, M., Cancela, A., Urréjola, S. and Sánchez, A., (2011). Macroalgae: raw material for biodiesel production. Applied Energy, 88(10):3318-3323.

[17] Medipally, S.R., Yusoff, F.M., Banerjee, S. and Shariff, M., (2015). Microalgae as sustainable renewable energy feedstock for biofuel production. BioMed research international, 1-15.

[18] Coppejans, E., Leliaert, F., Dargent, O., Gunasekara, R. and De Clerck, O., (2009). Sri Lankan seaweeds: Methodologies and field guide to the dominant species, 6:265, Belgian Development Cooperation.

[19] Gao, Y., Gregor, C., Liang, Y., Tang, D. and Tweed, C., (2012). Algae biodiesel-a feasibility report. Chemistry Central Journal, 6(1): S1.

[20] Griffiths, M.J. and Harrison, S.T., (2009). Lipid productivity as a key characteristic for choosing algal species for biodiesel production. Journal of Applied Phycology, 21(5):493-507.

[21] Rahman, M.M., Rasul, M.G., Hassan, N.M.S., Azad, A.K. and Uddin, M.N. (2017). Effect of small proportion of butanol additive on the performance, emission, and combustion of Australian native first-and second-generation biodiesel in a diesel engine. Environmental. Science. Pollution. Resourse. 24: 22402-22413a.

[22] Rahman, M., Rasul, M. and Hassan, N. (2017). Study on the tribological characteristics of Australian native first generation and second-generation biodiesel fuel. Energies, 10: 55b.

[23] Knothe, G., (2005). Dependence of biodiesel fuel properties on the structure of fatty acid alkyl esters. Fuel processing technology, 86(10):1059-1070. 
[24] Khan, A.M., Ameen, M. and Fatima, N., (2017). Production of green and renewable biodiesel from marine brown alga Sargassum tenerrimum.

[25] Khola, G. and Ghazala, B., (2012). Biodiesel production from algae. Pakistan. Journal of. Botany, 44(1):379-381.

[26] Meher, L.C., Sagar, D.V. and Naik, S.N., (2006). Technical aspects of biodiesel production by transesterification - a review. Renewable and sustainable energy reviews, 10(3):248-268.

[27] Leung, D.Y.C. and Guo, Y., (2006). Transesterification of neat and used frying oil: optimization for biodiesel production. Fuel processing technology, 87(10):883-890.

[28] Spolaore, P., Joannis-Cassan, C., Duran, E. and Isambert, A., (2006). Commercial applications of microalgae. Journal of bioscience and bioengineering, 101(2):87-96.

[29] Religia, P. and Wijanarko, A., (2015). Utilization of n-hexane as co-solvent to increase biodiesel yield on direct transesterification reaction from marine microalgae. Procedia Environmental Sciences, 23:412-420.

[30] Siddiqua, S., Al Mamun, A. and Babar, S.M.E., (2015). Production of biodiesel from coastal macroalgae (Chara vulgaris) and optimization of process parameters using Box-Behnken design. Springer plus, 4(1):720.

[31] Vicente, G., Martínez, M. and Aracil, J. (2007). Optimization of integrated biodiesel production. Part I. A study of the biodiesel purity and yield. Bioresource technology. 98:1724-1733.

[32] Hasni, K., Ilham, Z., Dharma, S. and Varman, M. (2017). Optimization of biodiesel production from Brucea javanica seeds oil as novel non-edible feedstock using response surface methodology. Energy Conservation Management. 149:392-400.

[33] Rawat, I., Kumar, R.R., Mutanda, T. and Bux, F., (2013). Biodiesel from microalgae: a critical evaluation from laboratory to large scale production. Applied energy, 103:444-467.

[34] Rabu, R.A., Janajreh, I. and Honnery, D., (2013). Transesterification of waste cooking oil: process optimization and conversion rate evaluation. Energy Conversion and Management, 65:764-769.

[35] Verma, M.L., Barrow, C.J. and Puri, M., (2013). Nanobiotechnology as a novel paradigm for enzyme immobilization and stabilization with potential applications in biodiesel production. Applied microbiology and biotechnology, 97(1): 23-39.

[36] Jassinnee Milano., Hwai Chyuan Ong., Masjukia, H.H., Chonga., W.T., Man Kee Lam., Ping Kwan Loh. and Viknes Vellayan, (2016). Microalgae fuels as an alternative to fossil fuel for power generation. Renwable and sustainable energy review. 58:180-197.

[37] Khan, N.A. and el Dessouky, H., (2009). Prospect of biodiesel in Pakistan. Renewable and Sustainable Energy Reviews, 13(6-7):1576-1583. 
[38] Pramanik, K., (2003). Properties and use of Jatropha curcas oil and diesel fuel blends in compression ignition engine. Renewable energy, 28(2):239-248.

[39] Turner, E.C. and Foster, W.A., (2009). The impact of forest conversion to oil palm on arthropod abundance and biomass in Sabah, Malaysia. Journal of Tropical Ecology, 25(1):23-30.

[40] Chakraborty, M., Miao, C., McDonald, A. and Chen, S., (2012). Concomitant extraction of bio-oil and value-added polysaccharides from Chlorella sorokiniana using a unique sequential hydrothermal extraction technology. Fuel, 95:63-70.

[41] Ahmed, A.S., Khan, S., Hamdan, S., Rahman, R., Kalam, A., Masjuki, H.H. and Mahlia, T.M.I., (2013). Biodiesel production from macro algae as a green fuel for diesel engine. Journal of Energy and Environment, 2(1):1-5.

[42] Ahmed, I., Ali, M., Ahmad, N. and Ahmad, I., (2015). Production of biodiesel from algae. Journal of pure and applied microbiology, $\mathbf{9 ( 1 ) : 7 9 - 8 5 . ~}$

[43] Aransiola, E.F., Ojumu, T.V., Oyekola, O.O., Madzimbamuto, T.F. and Ikhu-Omoregbe, D.I.O., (2014). A review of current technology for biodiesel production: State of the art. Biomass and bioenergy, 61:276-297.

[44] Patil, P.D., Gude, V.G., Mannarswamy, A., Deng, S., Cooke, P., Munson-McGee, S., Rhodes, I., Lammers, P. and Nirmalakhandan, N., (2011). Optimization of direct conversion of wet algae to biodiesel under supercritical methanol conditions. Bioresource technology, 102(1):118-122.

[45]Schenk, P.M., Thomas-Hall, S.R., Stephens, E., Marx, U.C., Mussgnug, J.H., Posten, C., Kruse, O. and Hankamer, B., (2008). Second generation biofuels: high-efficiency microalgae for biodiesel production. Bioenergy Research, 1(1):20-43.

[46] Kucukvar M, Tatari O. (2011). A comprehensive life cycle analysis of cofiring algae in a coal power plant as a solution for achieving sustainable energy. 36(11):6352-7. 